\title{
Antitumor and HIV-1 Reverse Transcriptase Inhibitory Activities of a Hemagglutinin and a Protease Inhibitor from Mini-Black Soybean
}

\author{
Xiu Juan Ye and Tzi Bun Ng \\ School of Biomedical Sciences, Faculty of Medicine, The Chinese University of Hong Kong, Shatin New Territories, Hong Kong \\ Correspondence should be addressed to Tzi Bun Ng, b021770@mailserv.cuhk.edu.hk
}

Received 20 May 2010; Revised 18 October 2010; Accepted 10 January 2011

Copyright () 2011 X. J. Ye and T. B. Ng. This is an open access article distributed under the Creative Commons Attribution License, which permits unrestricted use, distribution, and reproduction in any medium, provided the original work is properly cited.

Protease inhibitors (PIs) and hemagglutinins are defense proteins produced by many organisms. From Chinese mini-black soybeans, a 17.5-kDa PI was isolated using chromatography on Q-Sepharose, SP-Sepharose, and DEAE-cellulose. A 25-kDa hemagglutinin was purified similarly, but using Superdex 75 instead of DEAE-cellulose in the final step. The PI inhibited trypsin and chymotrypsin $\left(\mathrm{IC}_{50}=7.2\right.$ and $\left.8.8 \mu \mathrm{M}\right)$. Its trypsin inhibitory activity was stable from $\mathrm{pH} 2$ to $\mathrm{pH} 13$ and from $0^{\circ} \mathrm{C}$ to $70^{\circ} \mathrm{C}$. The hemagglutinin activity of the hemagglutinin was stable from $\mathrm{pH} 2$ to $\mathrm{pH} 13$ and from $0^{\circ} \mathrm{C}$ to $75^{\circ} \mathrm{C}$. The results indicated that both PI and hemagglutinin were relatively thermostable and $\mathrm{pH}$-stable. The trypsin inhibitory activity was inhibited by dithiothreitol, signifying the importance of the disulfide bond to the activity. The hemagglutinating activity was inhibited most potently by D (+)-raffinose and $\mathrm{N}$-acetyl-D-galactosamine, suggesting that the hemagglutinin was specific for these two sugars. Both PI and hemagglutinin inhibited HIV-1 reverse transcriptase $\left(\mathrm{IC}_{50}=3.2\right.$ and $\left.5.5 \mu \mathrm{M}\right)$, proliferation of breast cancer cells $\left(\mathrm{IC}_{50}=9.7\right.$ and $3.5 \mu \mathrm{M})$, and hepatoma cells ( $\mathrm{IC}_{50}=35$ and $\left.6.2 \mu \mathrm{M}\right)$, with relatively high potencies.

\section{Introduction}

Defense proteins including protease inhibitors are produced by a variety of organisms including animals [1] and plants [2-16]. Plants produce an array of defense proteins to combat noxious pathogens and predators. These defense proteins constitute a heterogeneous repertoire that comprises protease inhibitors [1-16], hemagglutinins [17], antifungal proteins [18], and ribosome inactivating proteins [19]. The defense proteins exert a diversity of actions such as immunomodulatory, antitumor/antiproliferative, and antiviral activities [2,13-16]. Among the protease inhibitors, trypsin inhibitors represent a frequently studied group. Hemagglutinins are also a subject of intensive investigation.

The seeds of leguminous plants are abundant in proteins which may include some of the aforementioned defense proteins. The mini-black cultivar of soybean (Glycine soja) has not been examined previously. An extract of this bean exhibits protease inhibitory and hemagglutinating activities. Since different cultivars of the same species may produce different proteins, we undertook the present study to isolate and characterize a protease inhibitor and a hemagglutinin from the mini-black soybean.

Soybean has many beneficial effects and can ameliorate some diseases [20-22]. An aqueous extract of soybean Glycine max exerted a significant antihyperglycemic action in alloxan-induced diabetic mice [23]. Using monocyte/ macrophage-like cell models [24], it has been demonstrated that a combination of avocado/soybean unsaponifiables and chondroitin sulfate can inhibit cytokine (TNF- $\alpha$ and IL-1 $\beta$ ) expression and prostaglandin $\mathrm{E}_{2}$ production. Osteoarthritis is characterized by inflammation and elevated production of proinflammatory mediators such as cytokines and prostaglandin E2. Macrophage-like cells in synovial tissue produce these mediators which induce cartilage-degrading enzymes. Hence, it is possible to make use of soybeans to inhibit osteoarthritis.

Black soybean has long been used in Chinese traditional medicine, as a detoxifier, an anti-inflammatory drug and a blood nutrient and for promoting urination. It suppresses the growth of transplantable human bladder carcinoma and tumor angiogenesis in mice [25], exhibits antioxidant 
activity, inhibits low density lipoprotein oxidation [26], and can be used for treating an ophthalmic disorder associated with retinal pigment epithelium disturbance [27]. The polysaccharides prepared from black soybeans [28] can also be used to stimulate cellular immunity by augmenting the production of cytokines and in preventing or treating leukemia. It is beneficial to the health of patients who have been infected by pathogens such as HIV, by elevating the blood cell number and enhancing the immune system [29]. Black soybean is more effective than yellow soybean in preventing menopausal symptoms. Ovariectomized menopausal rats fed on black soybeans demonstrated a significantly greater reduction in blood-cholesterol concentration, compared to rats fed on yellow soybeans. Consumption of black soybeans protects against bone loss in ovariectomized rats by inhibiting bone turnover and bone resorption [30]. Black soybean peptides when applied in vivo and in vitro reduce endoplasmic reticulum stress and improve insulin resistance [31], whilst anthocyanins from black soybean seed coats stimulate wound healing in fibroblasts and keratinocytes and prevent inflammation in endothelial cells [32]. They preferentially inhibit tumor necrosis factor-alpha-mediated induction of vascular cell adhesion molecule-1 over intercellular adhesion molecule1 through the regulation of transcription factor genes binding to DNA sequence GATA and interferon regulatory transcription factor-1 [33]. The anthocyanins inhibit UVBinduced inflammatory cylooxygenase-2 gene expression and $\mathrm{PGE}_{2}$ production through regulation of the nuclear factorkappaB and phosphatidylinositol 3-kinase/Akt pathway [34]. They also exert hypolipidemic and antiobesity actions [35]. Red soybean anthocyanins demonstrate an antitumor action [36].

Since black soybean has medicinal properties and its activities are reportedly more potent than those of yellow soybean, we undertook the present study to isolate a hemagglutinin and a protease inhibitor with antitumor and HIV-1 reverse transcriptase inhibitory activities from miniblack soybean which is a special type of black soybean.

\section{Materials and Methods}

2.1. Materials. Chinese mini-black soybeans (Glycine soja cv. "Mini-black Soybean") from China (100 g) were deposited in laboratory 302, School of Biomedical Sciences, The Chinese University of Hong Kong (CUHK) under voucher number LB302, after authentication by Professor Shiuying $\mathrm{Hu}$, Honorary Professor of Chinese Medicine, CUHK. SPSepharose, Q-Sepharose, and Superdex 75 HR10/30 columns and Purifier were bought from GE Healthcare (Hong Kong). DEAE-cellulose, Trizma base (98\% purity), $\mathrm{NaCl}$ (99\% purity), and $\mathrm{NH}_{4} \mathrm{OAc}$ (98\% purity) were obtained from Sigma Chemical Co., St. Louis, Missouri, USA.

2.2. Isolation of Protease Inhibitor and Hemagglutinin. The beans were extracted with distilled water $(10 \mathrm{~mL} / \mathrm{g})$ at room temperature in a Waring blender for 10 minutes, followed by centrifugation at $13000 \mathrm{~g}$ and $4^{\circ} \mathrm{C}$ for 30 minutes. Tris- $\mathrm{HCl}$ buffer ( $\mathrm{pH} 7.4,1 \mathrm{M}$ ) was added to the resulting supernatant until the final concentration of Tris attained $20 \mathrm{mM}$. The supernatant was then loaded on a $5 \mathrm{~cm} \times 20 \mathrm{~cm}$ column of Q-Sepharose in $20 \mathrm{mM}$ Tris- $\mathrm{HCl}$ buffer ( $\mathrm{pH}$ 7.4). After removal of unabsorbed proteins, the column was eluted with $0.2 \mathrm{M} \mathrm{NaCl}$ added to the Tris- $\mathrm{HCl}$ buffer. The fraction eluted with $0.2 \mathrm{M} \mathrm{NaCl}$ was dialyzed extensively against distilled water, and $1 \mathrm{M} \mathrm{NH}_{4} \mathrm{OAc}$ buffer ( $\mathrm{pH} 4.5$ ) was added until the $\mathrm{NH}_{4} \mathrm{OAc}$ concentration reached $100 \mathrm{mM}$. This was followed by ion exchange chromatography on a $2.5 \mathrm{~cm} \times 30 \mathrm{~cm}$ column of SP-Sepharose in the same buffer. After removal of unabsorbed proteins, the column was eluted with a linear $0-0.5 \mathrm{M} \mathrm{NaCl}$ gradient (total volume $650 \mathrm{~mL}$ ) added to the $\mathrm{NH}_{4} \mathrm{OAc}$ buffer. The protease inhibitor-enriched fraction SP1 was eluted with the $0-0.25 \mathrm{M} \mathrm{NaCl}$ gradient, and the hemagglutinin-enriched fraction SP3 was eluted with the $0.175-0.5 \mathrm{M} \mathrm{NaCl}$ gradient. Both fractions were dialyzed extensively against distilled water at $4^{\circ} \mathrm{C}$ overnight. In the case of the protease inhibitor-enriched fraction, the Tris concentration of the fraction was adjusted to $20 \mathrm{mM}$. This was followed by ion exchange chromatography on a $2.5 \mathrm{~cm}$ $\times 30 \mathrm{~cm}$ column of DEAE-cellulose in $20 \mathrm{mM}$ Tris- $\mathrm{HCl}$ buffer ( $\mathrm{pH}$ 7.4). After removal of unabsorbed proteins, the column was eluted sequentially with a $0-0.5 \mathrm{M} \mathrm{NaCl}$ gradient (total volume $480 \mathrm{~mL}$ ) added to the Tris- $\mathrm{HCl}$ buffer. Fraction D2, which was eluted with a $0.31-0.44 \mathrm{M} \mathrm{NaCl}$ gradient, was dialyzed against distilled water. D2 represented purified black soybean protease inhibitor. Hemagglutinin-enriched fraction SP3 was subjected to FPLC (fast protein liquid chromatography)-gel filtration on a Superdex 75 HR10/30 column using an AKTA Purifier.

2.3. Electrophoresis, Molecular Mass Determination, and Nterminal Amino Acid Sequence Analysis. The purified protease inhibitor/hemagglutinin was subjected to sodium dodecyl sulfate-polyacrylamide gel electrophoresis (SDSPAGE) for molecular mass determination. After electrophoresis, the gel was stained with Coomassie Brilliant Blue. The molecular mass of the isolated protein was determined by comparison of its electrophoretic mobility with those of molecular mass marker proteins from GE Healthcare. Gel filtration on an FPLC-Superdex 75 column, which had been calibrated with molecular mass markers (GE Healthcare), was conducted to determine the molecular mass of the protein. The N-terminal sequence of the protein was determined by using a Hewlett-Packard HP G1000A Edman degradation unit and a HP 1000 HPLC System.

\subsection{Trypsin-Inhibitory and Chymotrypsin-Inhibitory Activ- ities of Isolated Protease Inhibitor. Trypsin activity was determined by using casein from Sigma as substrate [35]. The assay for trypsin-inhibitory activity was carried out by addition of the test sample to $160 \mu \mathrm{L}$ of a $1 \%$ casein solution in $0.1 \mathrm{M}$ Tris- $\mathrm{HCl}$ buffer ( $\mathrm{pH}$ 7.4). Bovine pancreatic trypsin from Sigma $(20 \mu \mathrm{L}$ of a $0.5 \mathrm{mg} / \mathrm{mL}$ solution) was then added and the mixture was incubated at $37^{\circ} \mathrm{C}$ for 15 minutes before $0.4 \mathrm{~mL} \mathrm{5 \%}(\mathrm{w} / \mathrm{v})$ trichloroacetic acid was added to terminate the reaction. After centrifugation, the absorbance of the}


supernatant, which reflects the amount of casein fragments, was measured at $280 \mathrm{~nm}$.

The isolated trypsin inhibitor $(2.4 \mu \mathrm{M})$ was incubated with dithiothreitol (DTT) from Sigma, at final concentrations of $6 \mathrm{mM}, 32 \mathrm{mM}$, and $64 \mathrm{mM}$ for $25 \mathrm{~min}$ at $37^{\circ} \mathrm{C}$. For comparison, soybean trypsin inhibitor (Sigma) $(2.88 \mu \mathrm{M})$ was similarly treated. The reaction was terminated by adding iodoacetamide at twice the amount of thiol functions contained in each DTT concentration. The remaining trypsininhibitory activity was measured at $\mathrm{pH} 8$ as described above. The highest iodoacetamide concentration used in the test was devoid of any effect on the activity of trypsin and the trypsin-inhibitory activity of the isolated trypsin inhibitor and soybean trypsin inhibitor [8].

Chymotrypsin activity was determined by using $\mathrm{N}-\alpha-$ benzoyl-L-tyrosyl ethyl ester hydrochloride (BTEE) from Sigma as substrate and bovine pancreatic chymotrypsin (USB Corporation, Ohio, USA) [12]. When BTEE was used as substrate, $25 \mu \mathrm{L}$ of a serial concentration of purified trypsin inhibitor was incubated with $25 \mu \mathrm{L}$ chymotrypsin $\left(1 \mathrm{mg} / \mathrm{mL}\right.$ in $50 \mathrm{mM}$ Tris- $\mathrm{HCl}$ containing $0.2 \mathrm{M} \mathrm{CaCl}_{2}, \mathrm{pH}$ 7.6) for $5 \mathrm{~min}$ at $37^{\circ} \mathrm{C}$. The residual chymotrypsin activity was measured by adding $1.45 \mathrm{~mL} 0.25 \mathrm{mM} \mathrm{N}-\alpha$-benzoyl-Larginine ethyl ester (BAEE) as substrate. After immediate mixing by inversion the increase in A253 was recorded for $5 \mathrm{~min}$. Reactions without addition of test samples were used as positive control.

\subsection{Hemagglutinating Activity of Isolated Hemagglutinin.} Fifty microliters of a serial two-fold dilution of the hemagglutinin solution in a microtiter U-plate were mixed with $50 \mu \mathrm{L}$ of a $2 \%$ suspension of rabbit red blood cells in phosphate-buffered saline $(\mathrm{pH} 7.2)$ at $20^{\circ} \mathrm{C}$. The results were read after about $1 \mathrm{~h}$, when the blank had fully sedimented. One hemagglutination unit is defined as the reciprocal of the highest dilution exhibiting hemagglutination whilst specific activity is the number of hemagglutination units/mg protein [37].

Serial twofold dilutions of sugar (melibiose, L-arabinose, $\mathrm{D}(+)$-glucosamine, glucuronic acid, $\mathrm{D}(+)$-xylose, $\mathrm{D}$-galacturonic acid, $\alpha$-lactose, $\mathrm{D}(+)$-raffinose, mannitol, $\mathrm{D}(+)$ galactose, $\mathrm{D}$-glucose, $\mathrm{D}(+)$-fucose, $\mathrm{N}$-acetyl- $\mathrm{D}$-galactosamine, $\mathrm{D}(+)$-mannose, alpha-methyl-D-glucoside, D-galactonic acid, maltose, D-L-rhamnose, and xylitol from Sigma) samples were prepared in phosphate buffered saline (PBS). All of the dilutions were mixed with an equal volume $(25 \mu \mathrm{L})$ of a solution of the hemagglutinin with 3 hemagglutination units. The mixture was allowed to stand for $30 \mathrm{~min}$ at room temperature and then mixed with $50 \mu \mathrm{L}$ of a $2 \%$ rabbit erythrocyte suspension. The minimum concentration of the sugar in the final reaction mixture, which completely inhibited 3 hemagglutination units of the hemagglutinin preparation, was calculated [37].

2.6. Thermostability of Hemagglutinin and Protease Inhibitor. The hemagglutinin samples and trypsin inhibitor samples were kept separately at different temperatures $\left(10^{\circ} \mathrm{C}\right.$ to $100^{\circ} \mathrm{C}$, at $10^{\circ} \mathrm{C}$ intervals) for $30 \mathrm{~min}$. The hemagglutinating

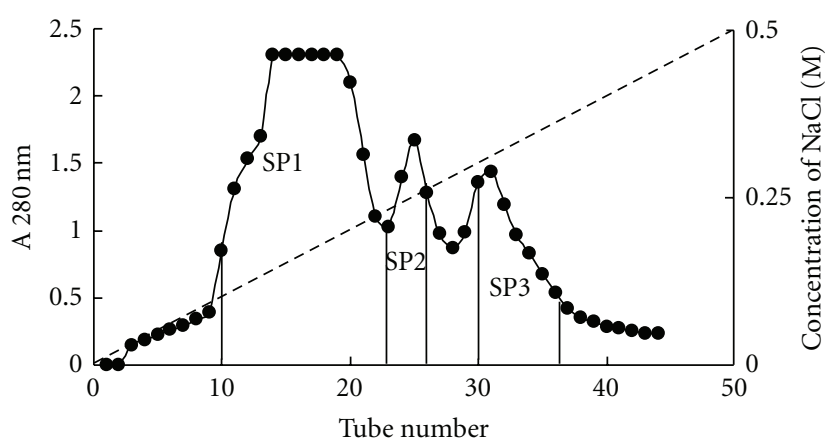

(a)

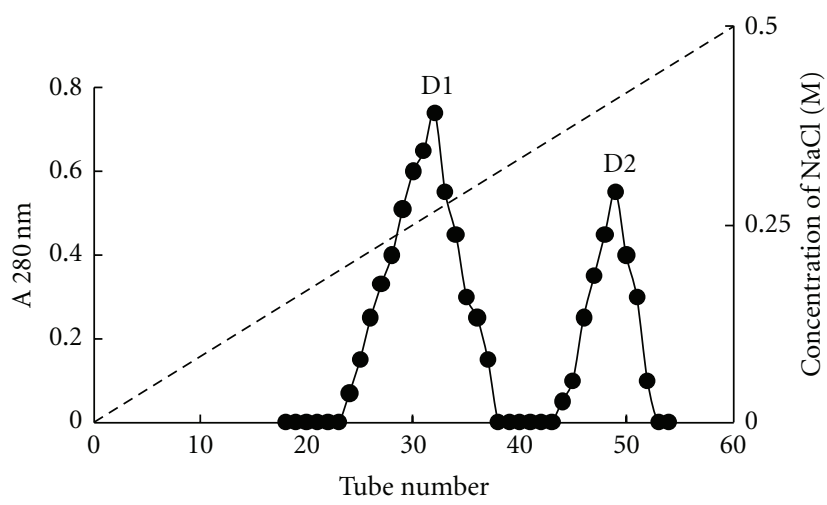

(b)

FIGURE 1: (a) Ion exchange chromatography on a SP-Sepharose column $(2.5 \mathrm{~cm} \times 30 \mathrm{~cm})$. Sample: fraction of the mini-black soybean extract adsorbed on Q-Sepharose and subsequently eluted by $0.2 \mathrm{M}$ $\mathrm{NaCl}$ in $20 \mathrm{mM}$ Tris-HCl buffer. The dotted slanting line represents the linear $\mathrm{NaCl}$ concentration gradient $(0-0.5 \mathrm{M})$ in $100 \mathrm{mM}$ $\mathrm{NH}_{4} \mathrm{OAc}$ buffer ( $\mathrm{pH}$ 4.5) used to elute the absorbed proteins from the column. Unabsorbed proteins eluted with $100 \mathrm{mM} \mathrm{NH}_{4} \mathrm{OAc}$ buffer ( $\mathrm{pH}$ 4.5) are not shown. Hemagglutinating activity was observed in fraction SP3. Trypsin-inhibitory activity was found in fraction SP1. Fraction size: $13 \mathrm{~mL}$, flow rate: $30 \mathrm{~mL} / \mathrm{h}$. Conc. Of $\mathrm{NaCl}$ (M---), and absorbance at $280 \mathrm{~nm}(\bullet)$. The vertical lines in the elution profile denote the pooling of eluate into SP1, SP2, and SP3. (b) Ion exchange chromatography on a DEAE-cellulose column $(2.5 \mathrm{~cm} \times 30 \mathrm{~cm})$. Sample: Fraction SP1, the first adsorbed fraction from SP-Sepharose. Adsorbed proteins were eluted from the column by using a linear $\mathrm{NaCl}$ concentration gradient $(0$ $0.5 \mathrm{M}$ ) in $20 \mathrm{mM}$ Tris-HCl buffer $(\mathrm{pH} 7.4)$ represented by the dotted slanting line across the chromatogram. Trypsin-inhibitory activity was observed only in fraction D2. Unabsorbed proteins eluted with $20 \mathrm{mM}$ Tris-HCl buffer ( $\mathrm{pH} 7.4)$ are not shown. Fraction size: $6 \mathrm{~mL}$, flow rate: $30 \mathrm{~mL} / \mathrm{h}$, Conc of $\mathrm{NaCl}(\mathrm{M}---)$, and absorbance at $280 \mathrm{~nm}(\bullet)$.

activity and trypsin-inhibitory activity were determined after returning to room temperature [37-40].

2.7. pH Stability of Hemagglutinin. The hemagglutinin samples were kept separately at different $\mathrm{pH}$ values (2 to 13 ) for $30 \mathrm{~min}$. After the $\mathrm{pH}$ had been adjusted to $\mathrm{pH} 7$, the hemagglutinating activity was determined [37-40]. 


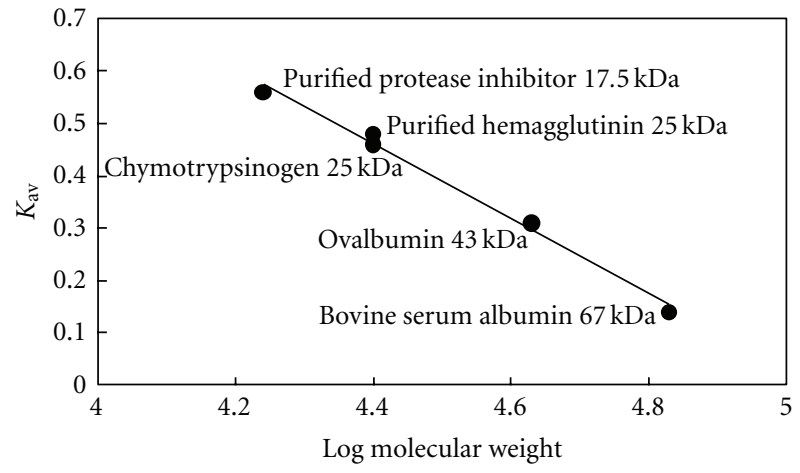

FIGURE 2: Standard curve for the molecular weight determination of the purified protease inhibitor and hemagglutinin from mini-black soybean using Superdex 75HR 10/30 chromatography on Superdex 75HR 10/30.

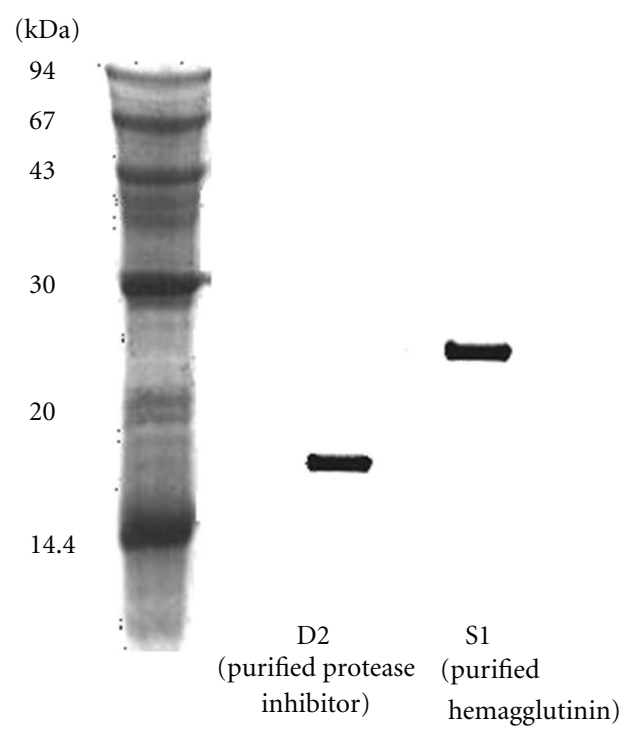

FIGURe 3: Results of SDS-PAGE after staining with Coomassie Brilliant Blue. Left lane: markers from GE Healthcare including phosphorylase b (94-kDa), bovine serum albumin $(67-\mathrm{kDa})$, ovalbumin $(43-\mathrm{kDa})$, carbonic anhydrase $(30-\mathrm{kDa})$, soybean trypsin inhibitor $(20-\mathrm{kDa})$, and $\alpha$-lactalbumin $(14.4-\mathrm{kDa})$. Middle lane: fraction D2 with trypsin-inhibitory activity from DEAE-cellulose column chromatography representing purified protease inhibitor. Right lane: fraction S1 from Superdex 75 column representing purified mini-black soybean hemagglutinin.

\subsection{Antiproliferative Activity of Isolated Protease Inhibitor} and Hemagglutinin on Tumor Cell Lines. Breast cancer (MCF-7) cells and hepatoma (HepG2) cells from American Type Tissue Collection were suspended in RPMI medium containing $10 \%$ fetal bovine serum, $100 \mathrm{U} / \mathrm{mL}$ penicillin, and $100 \mu \mathrm{g} / \mathrm{mL}$ streptomycin (Gibco) and adjusted to a cell density of $2 \times 10^{4}$ cells $/ \mathrm{mL}$. A $100 \mu \mathrm{L}$ aliquot of this cell suspension was seeded to a well of a 96-well plate, followed by incubation for 24 hours. Different concentrations of the protease inhibitor or hemagglutinin in $100 \mu \mathrm{L}$ complete RPMI medium were then added to the wells and incubated for 72 hours at $37^{\circ} \mathrm{C}$. After 72 hours, $20 \mu \mathrm{L}$

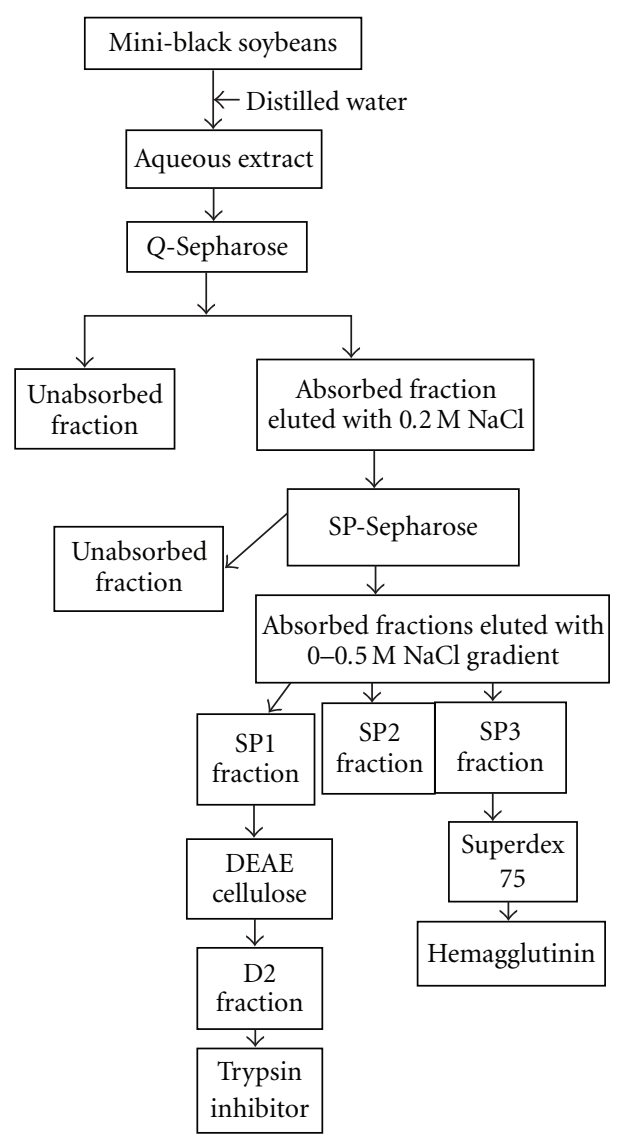

FIGURE 4: Flow chart summarizing the procedure used for isolating protease inhibitor and hemagglutinin from mini-black soybean.

of a $5 \mathrm{mg} / \mathrm{mL}$ solution of (3-[4,5-dimethylthiazol-2-yl]-2,5diphenyltetrazolium bromide) (MTT) in phosphate buffered saline was spiked into each well and the plates were incubated for 4 hours. The plates were then centrifuged at $324 \times \mathrm{g}$ for 5 minutes. The supernatant was carefully removed, and $150 \mu \mathrm{L}$ of dimethyl sulfoxide was added in each well to dissolve the MTT-formazan at the bottom of the wells. After 10 minutes, the absorbance at $590 \mathrm{~nm}$ was measured by using a microplate reader [18]. The defensin-like antifungal peptide sesquin from the bean Vigna sesquipedalis [18] was used as a positive control. Green lentil trypsin inhibitor [9] was used as a negative control in the assay.

\subsection{Ability of Isolated Protease Inhibitor and Hemagglutinin} to Inhibit HIV-1 Reverse Transcriptase Inhibitory Activity. The assay for ability to inhibit HIV reverse transcriptase inhibitory activity was carried out according to instructions supplied with the assay kit from Boehringer Mannheim (Germany). The assay takes advantage of the ability of reverse transcriptase to synthesize DNA, starting from the template/primer hybrid poly (A) oligo (dT) 15. The digoxigenin- and biotin-labeled nucleotides in an optimized ratio are incorporated into the DNA molecule, which is freshly synthesized by the reverse transcriptase (RT). The detection and quantification of synthesized DNA as a 


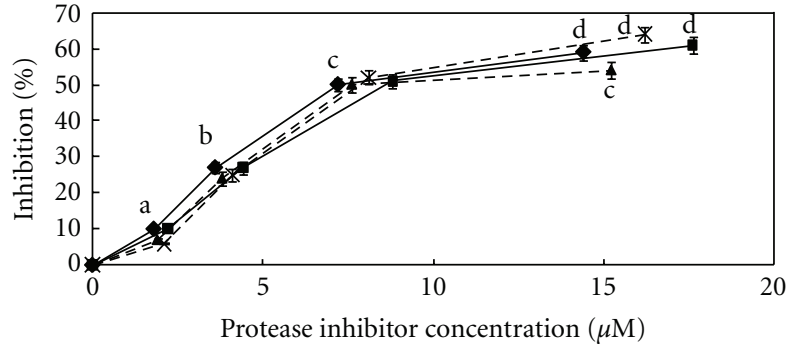

$\begin{array}{ll}- \text { MBSPI on trypsin activity } & \rightarrow \text { MBSPI on chymotrypsin activity } \\ -\downarrow-\text { STI on trypsin activity } & -\star-\text { STI on chymotrypsin activity }\end{array}$

(a)

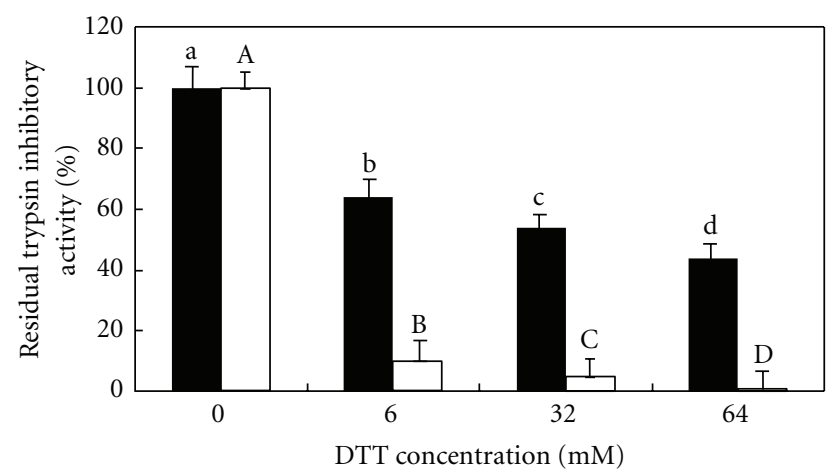

DTT on STI activity DTT on MBSPI activity

(b)

Figure 5: (a) Determination of $\mathrm{IC}_{50}$ values of trypsin- and chymotrypsin-inhibitory activities of mini-black soybean protease inhibitor (MBSTI) and soybean trypsin inhibitor (STI). Results are means \pm SD $(n=3)$. The protease inhibitor was incubated with bovine pancreatic trypsin and casein (for assay of trypsin inhibitory activity) or with $\mathrm{N}$ - $\alpha$-benzoyl-L-tyrosyl ethyl ester hydrochloride (for assay of chymotrypsin inhibitory activity) and bovine pancreatic chymotrypsin for 15 minutes in $0.1 \mathrm{M}$ Tris- $\mathrm{HCl}$ buffer ( $\mathrm{pH} 7.4$ ) before addition of $5 \%$ trichloroacetic acid. The reaction mixture was centrifuged and OD280 of the supernatant containing the tryptic fragments of casein was read. Background values were determined and subtracted before $\%$ inhibition values were calculated. Data points bearing the same letter represent statistically significant difference $(P<.05)$ when the data were analyzed by ANOVA followed by Duncan's multiple range test. (b) Effect of dithiothreitol (DTT) on trypsin-inhibitory activity of $2.4 \mu \mathrm{M}$ miniblack soybean (MBSPI) and $2.8 \mu \mathrm{M}$ trypsin inhibitor from soybean (STI) after incubation at $37^{\circ} \mathrm{C}$ for 25 minutes. Results are means \pm $\mathrm{SD}(n=3)$. The IC $\mathrm{I}_{50}$ of DTT was about $30 \mathrm{mM}$ on MBSPI and lower than $10 \mathrm{mM}$ on STI. The protease inhibitor $(1.8 \mathrm{mM})$ was incubated with dithiothreitol at various concentrations before termination of reaction with iodoacetamide and determination of remaining trypsin-inhibitory activity. Background values were determined and subtracted before \% inhibition values were calculated. Data points bearing the same letter represent statistically significant difference $(P<.05)$ when the data were analyzed by ANOVA followed by Duncan's multiple range test.

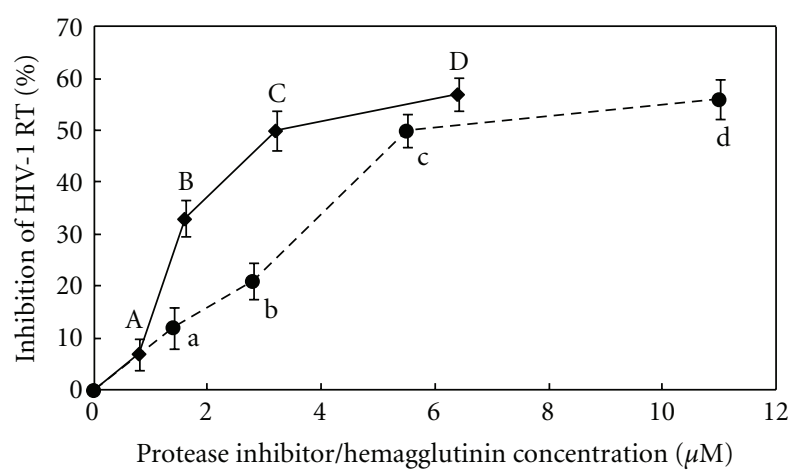

FIGURE 6: Inhibitory effect of mini-black soybean protease inhibitor $(\checkmark)$ and hemagglutinin $(\bullet)$ on HIV-1 reverse transcriptase activity. Results are means $\pm \mathrm{SD}(n=3)$. The inhibitory activities were determined with an ELISA kit from Boehringer Mannheim. Background values were determined and subtracted before \% inhibition values were calculated. Data points bearing the same letter represent statistically significant difference $(P<.05)$ when the data were analyzed by ANOVA followed by Duncan's multiple range test.

parameter for RT activity follow a sandwich ELISA protocol. Biotin-labeled DNA binds to the surface of microtiter plate modules that have been precoated with streptavidin. In the next step, an antibody to digoxigenin, conjugated to peroxidase, binds to the digoxigenin-labeled DNA. In the final step, the peroxidase substrate is added. The peroxidase enzyme catalyzes the cleavage of the substrate, producing a colored reaction product. The absorbance of the sample at $405 \mathrm{~nm}$ can be determined using a microtiter plate (ELISA) reader and is directly correlated to the level of RT activity. A fixed amount (4-6 ng) of recombinant HIV-1 reverse transcriptase was used. The inhibitory activity of the protease inhibitor/hemagglutinin was calculated as percent inhibition compared with the control without the protein [18]. The leguminous defensin-like protein sesquin was used as a positive control [18] and the antifungal protein mungin [41] as a negative control.

2.10. Antifungal Activity of Isolated Hemagglutinin and Protease Inhibitor. The assay of the isolated protease inhibitor/ hemagglutinin for antifungal activity toward Botrytis cinerea, Mycosphaerella arachidicola, and Fusarium oxysporum, which are plant pathogens, was carried out using $90 \times 15 \mathrm{~mm}$ petri plates containing $10 \mathrm{~mL}$ of potato dextrose agar. After the mycelial colony had developed, sterile blank paper disks $(0.625 \mathrm{~cm}$ in diameter $)$ were placed at a distance of $0.5 \mathrm{~cm}$ away from the rim of the mycelial colony. An aliquot of a solution of the protease inhibitor/hemagglutinin was added to a disk. After the plates had been incubated at $25^{\circ} \mathrm{C}$ for 72 hours, mycelial growth had enveloped disks containing the control and had formed crescents of inhibition around disks containing samples with antifungal activity. The leguminous defensin-like peptide sesquin was employed as a positive control [18] and emperor banana lectin [37] as a negative control. 


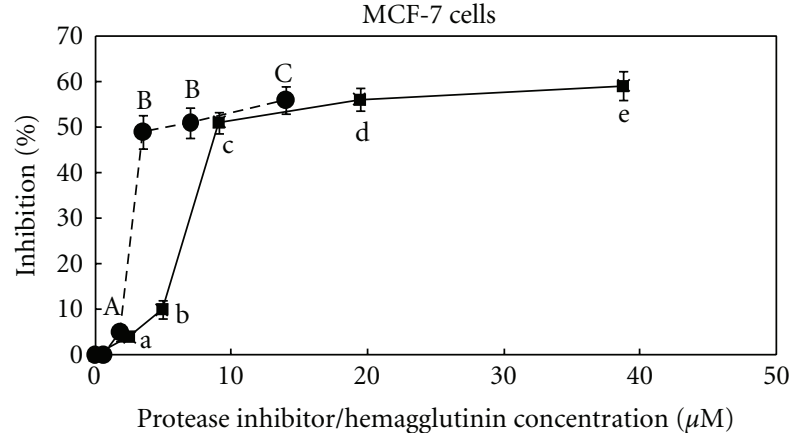

(a)

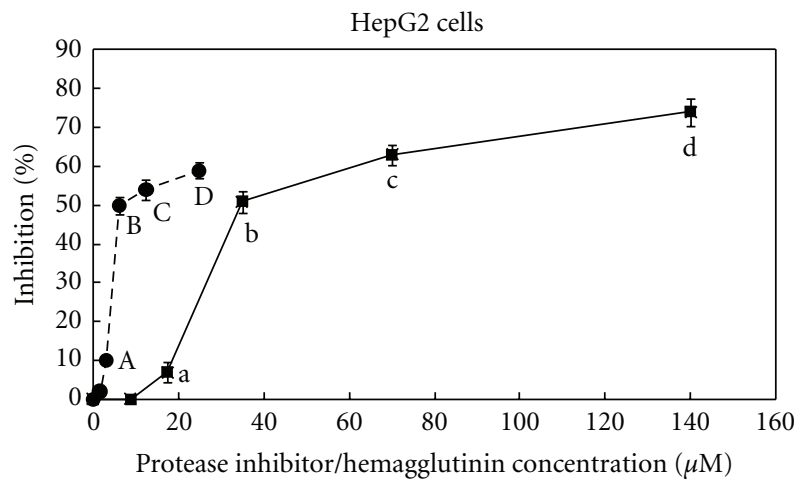

(b)

FIGURE 7: (a) Antiproliferative effect of mini-black soybean protease inhibitor $(\bullet)$ and hemagglutinin $(\bullet)$ on MCF-7 cells. Results are presented as means $\pm \mathrm{SD}(n=3)$. The inhibitor or lectin was incubated with $2 \times 10^{-3}$ MCF-7 cells in a 96-well plate for 72 hours prior to incubation with MTT for 4 hours. The plate was centrifuged and the supernatant removed before addition of DMSO to dissolve the MTT-formazan at the bottom of the well. $\mathrm{OD}_{590 \mathrm{~nm}}$ was then measured after 10 minutes. Background values were determined and subtracted before $\%$ inhibition values were calculated. Data points bearing the same letter represent statistically significant difference $(P<.05)$ when the data were analyzed by ANOVA followed by Duncan's multiple range test. (b) Antiproliferative effect of mini-black soybean protease inhibitor $(\checkmark)$ and hemagglutinin $(\bullet)$ on HepG2 cells. Results are means \pm SD $(n=3)$. The inhibitor or the hemagglutinin was incubated with $2 \times 10^{-3}$ HepG2 cells in a 96-well plate for 72 hours prior to incubation with MTT for 4 hours. The plate was centrifuged and the supernatant removed before addition of DMSO to dissolve the MTT-formazan at the bottom of the well. $\mathrm{OD}_{590 \mathrm{~nm}}$ was then measured after 10 minutes. Background values were determined and subtracted before \% inhibition values were calculated. Data points bearing the same letter represent statistically significant difference $(P<.05)$ when the data were analyzed by ANOVA followed by Duncan's multiple range test.

\section{Results}

3.1. Isolation of Protease-Inhibitor and Hemagglutinin. When the extract of mini-black soybeans was chromatographed on Q-Sepharose, trypsin-inhibitory activity, and hemagglutinating activity resided in the adsorbed fraction eluted by the linear concentration gradient of 0 to $0.2 \mathrm{M} \mathrm{NaCl}$, but not in the unabsorbed fraction. This adsorbed fraction was subsequently resolved on SP-Sepharose into an unabsorbed fraction (devoid of trypsin-inhibitory and hemagglutinating activities) and several adsorbed fractions, SP1, SP2, and SP3. Trypsin-inhibitory activity was detected in the largest adsorbed fraction SP1, and hemagglutinating activity was found in fraction SP3 which was much smaller in size (Figure 1(a)). Fraction SP1 was subsequently fractionated on DEAE-cellulose into an inactive unabsorbed fraction and two adsorbed fractions, D1 and D2 (Figure 1(b)). Trypsininhibitory activity was located only in fraction D2, which represented purified trypsin inhibitor. The molecular mass of D2 as determined by gel filtration on Superdex 75 was $17.5-\mathrm{kDa}$ (Figure 2). There was a 47 -fold purification of trypsin-inhibitory activity (Table 1). Hemagglutinating activity was adsorbed on Q-Sepharose and eluted with $0.2 \mathrm{M}$ $\mathrm{NaCl}$ in $20 \mathrm{mM}$ Tris- $\mathrm{HCl}$ buffer $(\mathrm{pH}$ 7.4). The fraction was subsequently adsorbed on SP-Sepharose and eluted in fraction SP3. Fraction SP3 appeared as a single peak upon gel filtration on Superdex 75. The peak had a molecular mass of $25-\mathrm{kDa}$ (Figure 2) and appeared as a single $25-\mathrm{kDa}$ band in SDS-PAGE (Figure 3). The purified protease inhibitor demonstrated a molecular mass of $17.5-\mathrm{kDa}$ in SDS-PAGE (Figure 3). A summary of purification of the hemagglutinin is provided in Table 2. Figure 4 is a flow chart illustrating the scheme for concurrent isolation of the protease inhibitor and hemagglutinin.

3.2. N-Terminal Sequences of Trypsin Inhibitor and Lectin. The data are shown in Table 3. Considerable homology to their counterparts from soybean is observed.

3.3. Biological Activities of Protease Inhibitor and Hemagglutinin. The isolated protease inhibitor inhibited trypsin with an $\mathrm{IC}_{50}$ of $7.2 \pm 0.5 \mu \mathrm{M}$ (mean $\pm \mathrm{SD}, n=3$ ) (Figure $5(\mathrm{a})$ ), and chymotrypsin with an $\mathrm{IC}_{50}$ of $8.8 \pm 0.2 \mu \mathrm{M}$ (mean \pm SD, $n=3$ ) (Figure 5(a)). Dithiothreitol inhibited the trypsin-inhibitory activity of the protease inhibitor in a dosedependent manner (Figure 5(b)). The trypsin-inhibitory activity of the protease inhibitor and the hemagglutinating activity of the lectin were stable from $\mathrm{pH} 2$ to $\mathrm{pH} 13$ (data not shown). Activity was fully preserved from $0^{\circ} \mathrm{C}$ to $70^{\circ} \mathrm{C}$ for the protease inhibitor and from $0^{\circ} \mathrm{C}$ to $75^{\circ} \mathrm{C}$ for the hemagglutinin (data not shown).

The protease inhibitor and the hemagglutinin inhibited HIV-1 reverse transcriptase with an $\mathrm{IC}_{50}$ of $3.2 \pm 0.2 \mu \mathrm{M}$ and $5.5 \pm 0.5 \mu \mathrm{M}$ (Figure 6), and suppressed proliferation of MCF-7 breast cancer cells with an IC $_{50}$ of $9.7 \pm 0.3 \mu \mathrm{M}$ and $3.5 \pm 0.2 \mu \mathrm{M}$ (Figure 7(a)), and HepG2 hepatoma cells with an $\mathrm{IC}_{50}$ of $35 \pm 0.3 \mu \mathrm{M}$ and $6.2 \pm 0.3 \mu \mathrm{M}$ (Figure 7(b)), respectively. The hemagglutinating activity of the hemagglutinin was inhibited by sugars with the following ranking of potencies: $\mathrm{D}(+)$ - raffinose $=\mathrm{N}$-acetyl-D-galactosamine $\ggg$ melibiose $=$ L-arabinose $>\alpha$-lactose $>\mathrm{D}(+)$-glucosamine $>$ glucuronic acid $>\mathrm{D}(+)$-fucose (Table 4$)$.

Neither the protease inhibitor nor the hemagglutinin demonstrated antifungal activity when tested up to $100 \mu \mathrm{M}$ (data not shown). Biological activities which the isolated 


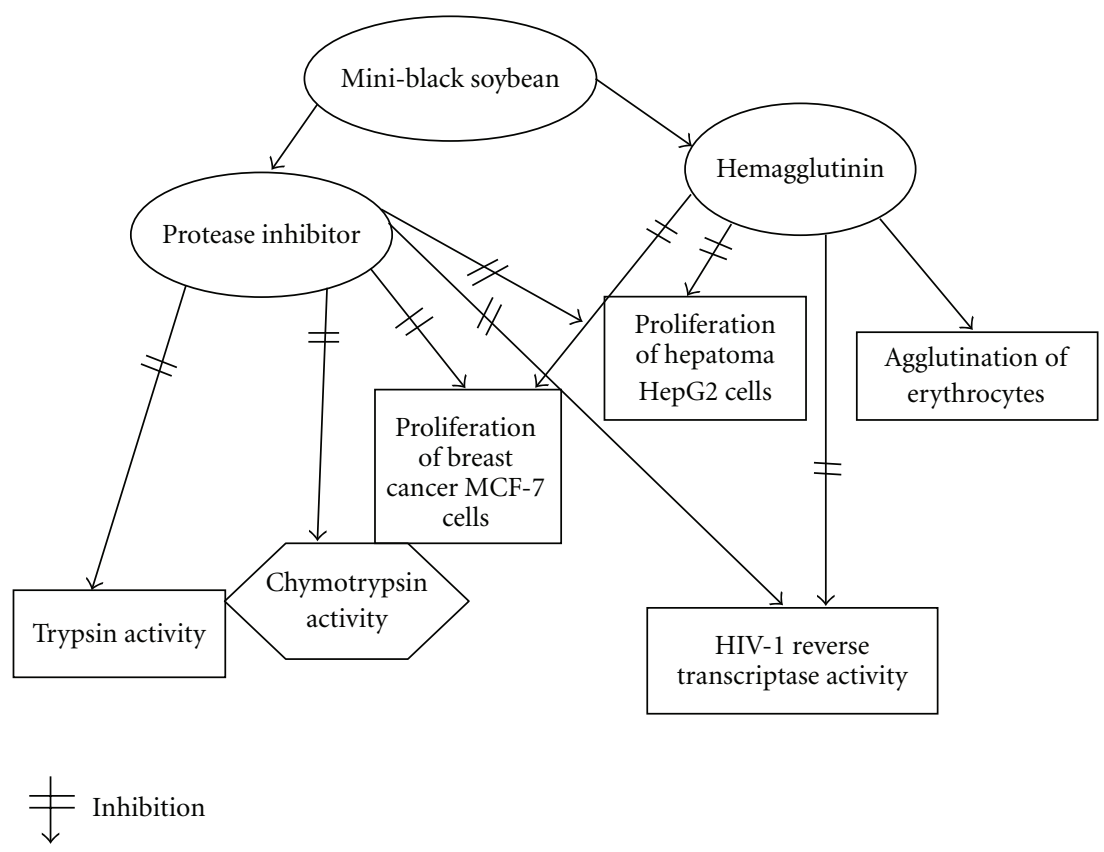

FIGURE 8: Biological activities of protease inhibitor and hemagglutinin from mini-black soybean.

TABLE 1: Yields (from $50 \mathrm{~g}$ beans) and trypsin-inhibitory activities of various chromatographic fractions obtained during different steps of purification of mini-black soybean protease inhibitor.

\begin{tabular}{lccccc}
\hline Fraction & $\begin{array}{c}\text { Total protein } \\
(\mathrm{mg})\end{array}$ & $\begin{array}{c}\text { Total trypsin-inhibitory } \\
\text { activity }(\mathrm{u})\end{array}$ & $\begin{array}{c}\text { Specific trypsin-inhibitory } \\
\text { activity }(\mathrm{u} / \mathrm{mg})\end{array}$ & $\begin{array}{c}\text { Recovery of trypsin-inhibitory } \\
\text { activity }(\%)\end{array}$ & $\begin{array}{c}\text { Fold of } \\
\text { purification }\end{array}$ \\
\hline Extract & 9800 & 17640 & 1.8 & 100 & 1 \\
Q & 625 & 9375 & 15 & 53.1 & 8.3 \\
SP1 & 242 & 8228 & 34 & 46.6 & 18.9 \\
D2 & 53 & 4505 & 85 & 25.5 & 47.2 \\
\hline
\end{tabular}

TABLE 2: Yields (from $50 \mathrm{~g}$ beans) and hemagglutinating activities of various chromatographic fractions obtained during different steps of purification of mini-black soybean hemagglutinin. HA: hemagglutinating.

\begin{tabular}{lccccc}
\hline Fraction & $\begin{array}{c}\text { Total protein } \\
(\mathrm{mg})\end{array}$ & $\begin{array}{c}\text { Total HA activity } \\
(\mathrm{u})\end{array}$ & $\begin{array}{c}\text { Specific HA activity } \\
(\mathrm{u} / \mathrm{mg})\end{array}$ & $\begin{array}{c}\text { Recovery of HA activity } \\
(\%)\end{array}$ & $\begin{array}{c}\text { Fold of } \\
\text { purification }\end{array}$ \\
\hline Extract & 9800 & 87220 & 8.9 & 100 & 1 \\
Q & 625 & 30010 & 48 & 34.4 & 5.3 \\
SP3 & 23 & 5888 & 256 & 6.8 & 28.8 \\
S & 18 & 5526 & 307 & 6.3 & 34.5 \\
\hline
\end{tabular}

TABLE 3: N-terminal sequences of protease inhibitor and hemagglutinin from mini-black soybean.

\begin{tabular}{lccc}
\hline & $\begin{array}{l}\text { Residue } \\
\text { number }\end{array}$ & Sequence & $\begin{array}{l}\text { Residue } \\
\text { number }\end{array}$ \\
\hline $\begin{array}{l}\text { Kunitz-type trypsin inhibitor from } \\
\text { mini-black soybean }(\text { Glycine soja) }\end{array}$ & 1 & GFVLDNQGNPLQNGGTYYLLSDITAFGGIRAAPTGNERYPLTVVQS & 47 \\
\hline $\begin{array}{l}\text { Trypsin inhibitor subtype B from yellow } \\
\text { soybean }(\text { Glycine max) }\end{array}$ & 1 & DVLDNEGNPLQNGGTYYILSDITAFGGIRAAPTGNERYPLTVVQS & 47 \\
\hline mini-black soybean hemagglutinin & 1 & AQTVSFSSWNKFVPKQPNILQGDAEVTSTGKLQLKAVKN & 39 \\
\hline yellow soybean lectin & 1 & AETTSFSITK FVPDQKNLIFQGDAEVTSTGKLKLKAVKN & 39 \\
\hline
\end{tabular}


TABLE 4: Effect of various carbohydrates on hemagglutinating activity of mini-black soybean hemagglutinin. Initial hemagglutinating activity was 3 hemagglutinating units, +: hemagglutination in presence of sugar, -: no hemagglutination in presence of sugar.

\begin{tabular}{|c|c|c|c|c|c|c|c|c|}
\hline Sugar (mM) & 1.6 & 3.12 & 6.25 & 12.5 & 25 & 50 & 100 & 200 \\
\hline Melibiose & + & + & + & + & - & - & - & - \\
\hline L-Arabinose & + & + & + & + & - & - & - & - \\
\hline $\mathrm{D}(+)$-Glucosamine & + & + & + & + & + & + & - & - \\
\hline Glucuronic acid & + & + & + & + & + & + & - & - \\
\hline $\mathrm{D}(+)$-Xylose & + & + & + & + & + & + & + & + \\
\hline D-Galacturonic acid & + & + & + & + & + & + & + & + \\
\hline$\alpha$-Lactose & + & + & + & + & + & - & - & - \\
\hline $\mathrm{D}(+)$-Raffinose & - & - & - & - & - & - & - & - \\
\hline Mannitol & + & + & + & + & + & + & + & + \\
\hline $\mathrm{D}(+)$-Galactose & + & + & + & + & + & + & + & + \\
\hline D-Glucose & + & + & + & + & + & + & + & + \\
\hline $\mathrm{D}(+)$-Fucose & + & + & + & + & + & + & - & - \\
\hline N-Acetyl-D-Galactosamine & - & - & - & - & - & - & - & - \\
\hline $\mathrm{D}(+)$-Mannose & + & + & + & + & + & + & + & + \\
\hline Alpha-Methyl-D-Glucoside & + & + & + & + & + & + & + & + \\
\hline D-Galactonic acid & + & + & + & + & + & + & + & + \\
\hline Maltose & + & + & + & + & + & + & + & + \\
\hline D-L-Rhamnose & + & + & + & + & + & + & + & + \\
\hline Xylitol & + & + & + & + & + & + & + & + \\
\hline
\end{tabular}

protease inhibitor and hemagglutinin have in common are shown in Figure 8.

\subsection{Comparison of Hemagglutinin and Protease Inhibitor from} Mini-Black Soybean with Those from Soybean. The comparison is shown in Tables 5 and 6. Some differences are noted between proteins from the two cultivars of soybean.

\section{Discussion}

We report herein the concurrent purification of a protease inhibitor and a hemagglutinin from the mini-black soybean. Both proteins are adsorbed on Q-Sepharose and SP-Sepharose but can be resolved from one another by using a linear $\mathrm{NaCl}$ concentration $(0-0.5 \mathrm{M})$ gradient to elute adsorbed proteins from the SP-Sepharose column. The hemagglutinin is more strongly adsorbed on SP-Sepharose than the protease inhibitor. It requires only two steps, ion exchange chromatography on Q-Sepharose and SPSepharose, to purify the hemagglutinin since it appears as a single band in SDS-PAGE and a single peak in gel filtration after SP-Sepharose chromatography. In a previous investigation, simultaneous purification of a protease inhibitor and a hemagglutinin from Pseudostellaria heterophylla roots has been achieved. Both the protease inhibitor and the lectin are unabsorbed on DEAE-cellulose and adsorbed on CMcellulose. They can be separated from one another by gel filtration on Superdex 75 in which the $36-\mathrm{kDa}$ lectin appears as the first peak and the $20.5-\mathrm{kDa}$ protease inhibitor is eluted as the second peak [38]. Similar to protease inhibitors from other leguminous seeds such as broad bean [2], mini-black soybean protease inhibitor is also a chymotrypsin inhibitor. The ability of the reducing agent dithiothreitol to reduce the trypsin-inhibitory activity of mini-black soybean protease inhibitor in a dose-dependent manner, as in the case of trypsin-inhibitor from papaya [8], revealed the importance of disulfide bonds to the trypsin-inhibitory activity. The ability of mini-black soybean protease inhibitor to inhibit proliferation of hepatoma and breast cancer cells is in compliance with earlier reports of the antitumor/antiproliferative activity of leguminous protease inhibitors [14-17]. The HIV1 reverse transcriptase inhibitory activity of the protease inhibitor is also in agreement with previous findings on trypsin inhibitors from the broad bean [2] and wampee [11]. However, it is noteworthy that some trypsin inhibitors like those of lentil [9], Vigna mungo [39], and lily bulbs [40] are devoid of antiproliferative activity toward tumor cells and exhibit very weak or no $\mathrm{HIV}-1$ reverse transcriptase inhibitory activity. The mechanism of the inhibitory action on the retroviral enzyme may be protein-protein interaction [42-44]. HIV-1 protease inhibits the homologous reverse transcriptase with this mechanism [44]. Unlike broad bean trypsin inhibitor [2] but similar to those of lentil [9], Vigna mungo [39], and lily bulbs [40], the protease inhibitor isolated in the present study does not suppress mycelial growth. It is a Kunitz-type trypsin inhibitor as evidenced by its molecular mass and N-terminal sequence.

The hemagglutinin isolated in the present study is capable of potently inhibiting HIV-1 reverse transcriptase. Some hemagglutinins have been shown to suppress HIV replication [45] and reduce HIV infectivity [46] and infections [47] while other hemagglutinins inhibit the retroviral reverse transcriptase $[48,49]$. The hemagglutinin also exerts its 
TABLE 5: Comparison of lectins from different cultivars of soybean.

\begin{tabular}{lcc}
\hline & Soybean lectin & Chinese mini-black soybean hemagglutinin \\
\hline Molecular weight & $122 \mathrm{kDa}$ & $25 \mathrm{kDa}$ \\
No. of subunits & 4 & 1 \\
Sugar specificity & N-acetylgalactosamine & $\mathrm{D}(+)$-raffinose \\
pH stability & $\mathrm{pH} 2-13$ & $\mathrm{pH} 2-13$ \\
Thermostability & $\mathrm{Up}$ to $50^{\circ} \mathrm{C}$ & $\mathrm{Up}^{\text {to }} 75^{\circ} \mathrm{C}$ \\
Antitumor activity & Present & $\mathrm{HepG}^{\mathrm{I}} \mathrm{IC}_{50}: 6.2 \mu \mathrm{M}$ \\
Inhibitory activity of HIV-1 reverse transcriptase & Present & $\mathrm{MCF}^{-7} \mathrm{IC}_{50}: 3.5 \mu \mathrm{M}$ \\
\hline
\end{tabular}

TABLE 6: Comparison of trypsin inhibitors from different cultivars of soybean.

\begin{tabular}{lcc}
\hline & Soybean trypsin inhibitor & Chinese mini-black soybean Protease inhibitor \\
\hline Molecular weight & $20 \mathrm{kDa}$ & $17.5 \mathrm{kDa}$ \\
Monomeric/with subunits & Monomeric & Monomeric \\
pH stability & $\mathrm{pH} \mathrm{3-13}$ & $\mathrm{pH} 2-13$ \\
Thermostability & Not done & $\mathrm{Up}^{\circ}$ to $70^{\circ} \mathrm{C}$ \\
Trypsin inhibitory activity & $\mathrm{IC}_{50}: 7.2 \mu \mathrm{M}$ & $\mathrm{IC}_{50}: 8.8 \mu \mathrm{M}$ \\
Chymotrypsin inhibitory activity & $\mathrm{IC}_{50}: 7.6 \mu \mathrm{M}$ & $\mathrm{IC}_{50}: 7.9 \mu \mathrm{M}$ \\
Inhibition of trypsin inhibitor by DTT $\left(\mathrm{IC}_{50}\right)$ & Lower than $10 \mathrm{mM}$ & $30 \mathrm{mM}$ \\
\hline
\end{tabular}

potent antiproliferative activity against hepatoma HepG2 and breast cancer MCF-7 cells, the findings are in line with previous reports on the antiproliferative/antitumor activity of other hemagglutinins [17, 47-56]. Lectins and lectin-containing extracts induce apoptosis [57] and regulate the expression of apoptotic genes in cancer cells $[58,59]$. It is highly likely that mini-black soybean hemagglutinin exerts its antitumor effects on breast cancer MCF-7 cells with a mechanism similar to that employed by French bean hemagglutinin [58]. The hemagglutinin demonstrates a higher antiproliferative activity on hepatoma and breast cancer cells than the protease inhibitor. However, it manifests a weaker HIV-1 reverse transcriptase inhibitory activity than the protease inhibitor.

Results of the present investigation on a Chinese cultivar of black soybean show some differences from earlier reports on soybean trypsin inhibitor and soybean lectin. The early findings were on a Bowman-Birk type trypsin inhibitor with a molecular mass of about $8-\mathrm{kDa}$ and a Kunitz-type trypsin inhibitor with a molecular mass of about 21-kDa [16]. However, only a single $17.5-\mathrm{kDa}$ Kunitz-type inhibitor was found in the present study. Soybean lectin reported in the literature is specific for galactose. The hemagglutinin isolated in the present study has a sugar specificity toward both $\mathrm{D}(+)$ raffinose and $\mathrm{N}$-acetylgalactosamine. Both protease inhibitor and hemagglutinin isolated in the present study have potent HIV-1 reverse transcriptase inhibitory and antiproliferative activities with $\mathrm{IC}_{50}$ values mostly below $10 \mu \mathrm{M}$. It appears that mini-black soybean may have health promoting effects.

The two proteins isolated in the present study are devoid of antifungal activity. Some $[2,11]$ but not other $[9,12]$ protease inhibitors display antifungal activity. Similarly, to date only a small number of hemagglutinins with antifungal activity have been reported $[60,61]$.

Different cultivars of the same plant species may produce different proteins. For instance, different cultivars of the pea Pisum sativum produce the ribosome inactivating protein pisavin [19] and the antifungal protein sativin [62], respectively. Different cultivars of the bean Phaseolus vulgaris including the pinto bean, flageolet bean, haricot bean, French bean, and red kidney bean produce different lectins [63]. From the Japanese black soybean [64], a BowmanBirk trypsin inhibitor with antiproliferative activity but no Kunitz-type trypsin inhibitor has been isolated. Both types of trypsin inhibitor are produced by the soybean [2] but only a Kunitz-type trypsin inhibitor is elaborated by the miniblack soybean cultivar. The number and type of protease inhibitor produced by soybean depend on the cultivar. Hemagglutinins produced by different soybean cultivars may also be different. The results of the present investigation are in line with the aforementioned observation.

Antiviral activity against two respiratory illness viruses, human adenovirus type 1 and coxsackie virus B1, has been demonstrated in a hot-water extract of black soybean. In contrast, the hot-water extract of common yellow soybean exhibited much lower activity. Neither saponins nor anthocyanins account for the antiviral activity. A partially purified hydrophilic and anionic antiviral compound was obtained by gel filtration, reversed phase HPLC, and ion-exchange HPLC. It showed maximum absorption at $260 \mathrm{~nm}$, indicating the presence of phenyl groups. Amino acid analysis and neutral sugar analysis disclosed that the antiviral compound is not a protein or glycoconjugate with neutral sugars [65]. 
Anthocyanidins are possible anti-inflammatory agents; however, further studies are required to determine required intake levels in vivo to exert antitumor effect [66]. The anticancer therapeutic potential of soy isoflavone genistein was reviewed by Ravindranath et al. [67].

The aforementioned investigations conducted by other groups revealed the antiviral and antitumor activities of nonproteinaceous constituents of black soybean. The present study demonstrated that protein components of black soybean exhibit these activities.

Soybean trypsin inhibitor remains stable for 60 minutes in simulated gastric fluid. The bulk of soybean lectin is digested within 8 minutes. The results on simulated gastric fluid differ from those on simulated intestinal fluid. Soybean trypsin inhibitor, soybean lectin, and peanut lectin are stable for 60 minutes in simulated intestinal fluid [68]. The legume lectin Griffonia simplicifolia lectin II [69] and banana lectin [70] are trypsin-stable. Thus, it is likely that soybean trypsin inhibitor and soybean lectin are relatively stable after passage through the gastrointestinal tract.

In this investigation, a protease inhibitor and a hemagglutinin, with some differences in characteristics from soybean trypsin inhibitor and soybean lectin reported earlier, have been isolated using some protocol from a Chinese cultivar of soybean, the mini-black soybean. In traditional Chinese medicine, black soybean is more nutritious and reinvigorating than soybean. The finding of a hemagglutinin and a protease inhibitor from black soybean, both with relatively stable medicinal activities including HIV-1 reverse transcriptase inhibitory and antiproliferative activities, at least partially account for its use in traditional Chinese medicine.

\section{Acknowledgment}

The award of a direct grant from the Medicine Panel, CUHK Research Committee, is gratefully acknowledged.

\section{References}

[1] M. Zhao, R. J. Naudé, K. Muramoto, and W. Oelofsen, "Purification and characterization of ostrich pancreatic secretory trypsin inhibitor," International Journal of Peptide and Protein Research, vol. 48, no. 2, pp. 174-181, 1996.

[2] X. Y. Ye, T. B. Ng, and P. F. Rao, "A bowman-birk-type trypsinchymotrypsin inhibitor from broad beans," Biochemical and Biophysical Research Communications, vol. 289, no. 1, pp. 9196, 2001.

[3] R. Conners, A. V. Konarev, J. Forsyth et al., "An unusual helix-turn-helix protease inhibitory motif in a novel trypsin inhibitor from seeds of Veronica (Veronica hederifolia L.)," Journal of Biological Chemistry, vol. 282, no. 38, pp. 2776027768, 2007.

[4] J. Kowalska, K. Pszczoła, A. Wilimowska-Pelc et al., "Trypsin inhibitors from the garden four o'clock (Mirabilis jalapa) and spinach (Spinacia oleracea) seeds: isolation, characterization and chemical synthesis," Phytochemistry, vol. 68, no. 11, pp. 1487-1496, 2007.

[5] E. von Hofe, P. M. Newberne, and A. R. Kennedy, "Inhibition of N-nitrosomethylbenzylamine-induced esophageal neoplasms by the Bowman-Birk protease inhibitor," Carcinogenesis, vol. 12, no. 11, pp. 2147-2150, 1991.

[6] R. C. H. Wong, W. P. Fong, and T. B. Ng, "Multiple trypsin inhibitors from Momordica cochinchinensis seeds, the Chinese drug mubiezhi," Peptides, vol. 25, no. 2, pp. 163-169, 2004.

[7] A. S. Oliveira, L. Migliolo, R. O. Aquino et al., "Purification and characterization of a trypsin-papain inhibitor from Pithecelobium dumosum seeds and its in vitro effects towards digestive enzymes from insect pests," Plant Physiology and Biochemistry, vol. 45, no. 10-11, pp. 858-865, 2007.

[8] M. Azarkan, R. Dibiani, E. Goormaghtigh, V. Raussens, and D. Baeyens-Volant, "The papaya Kunitz-type trypsin inhibitor is a highly stable $\beta$-sheet glycoprotein," Biochimica et Biophysica Acta, vol. 1764, no. 6, pp. 1063-1072, 2006.

[9] A. H. K. Cheung and B. N. Tzi, "Isolation and characterization of a trypsin-chymotrypsin inhibitor from the seeds of green lentil (Lens culinaris)," Protein and Peptide Letters, vol. 14, no. 9, pp. 859-864, 2007.

[10] M. F. Troncoso, P. C. Zolezzi, U. Hellman, and C. WolfensteinTodel, "A novel trypsin inhibitor from Peltophorum dubium seeds, with lectin-like properties, triggers rat lymphoma cell apoptosis," Archives of Biochemistry and Biophysics, vol. 411, no. 1, pp. 93-104, 2003.

[11] T. B. Ng, S. K. Lam, and W. P. Fong, "A homodimeric sporamin-type trypsin inhibitor with antiproliferative, HIV reverse transcriptase-inhibitory and antifungal activities from wampee (Clausena lansium) seeds," Biological Chemistry, vol. 384, no. 2, pp. 289-293, 2003.

[12] A. Y. K. Tsoi, T. B. Ng, and W. P. Fong, "Immunomodulatory activity of a chymotrypsin inhibitor from Momordica cochinchinensis seeds," Journal of Peptide Science, vol. 12, no. 9, pp. 605-611, 2006.

[13] A. R. Kennedy, "The evidence for soybean products as cancer preventive agents," Journal of Nutrition, vol. 125, no. 3, 1995.

[14] A. O. Fernandes and A. P. Banerji, "The field bean protease inhibitor can effectively suppress 7,12dimethylbenz[a] anthracene-induced skin tumorigenesis in mice," Cancer Letters, vol. 104, no. 2, pp. 219-224, 1996.

[15] H. Kobayashi, M. Suzuki, N. Kanayama, and T. Terao, "A soybean Kunitz trypsin inhibitor suppresses ovarian cancer cell invasion by blocking urokinase upregulation," Clinical and Experimental Metastasis, vol. 21, no. 2, pp. 159-166, 2004.

[16] Y. Birk, Plant Protease Inhibitors, Springer, Berlin, Germany, 2003.

[17] J. H. Wong and T. B. Ng, "Isolation and characterization of a glucose/mannose/rhamnose-specific lectin from the knife bean Canavalia gladiata," Archives of Biochemistry and Biophysics, vol. 439, no. 1, pp. 91-98, 2005.

[18] J. H. Wong and T. B. Ng, "Sesquin, a potent defensin-like antimicrobial peptide from ground beans with inhibitory activities toward tumor cells and HIV-1 reverse transcriptase," Peptides, vol. 26, no. 7, pp. 1120-1126, 2005.

[19] S. S. L. Lam, H. Wang, and T. B. Ng, "Purification and characterization of novel ribosome inactivating proteins, alpha- and beta-pisavins, from seeds of the garden pea Pisum sativum," Biochemical and Biophysical Research Communications, vol. 253, no. 1, pp. 135-142, 1998.

[20] Y. E. Choi, S. K. Ahn, W. T. Lee et al., "Soybeans ameliorate diabetic nephropathy in rats," Evidence-Based Complementary and Alternative Medicine, vol. 7, pp. 443-440, 2010.

[21] R. Shin, M. Suzuki, T. Mizutani, and N. Susa, "Improvement of experimentally induced hepatic and renal disorders in rats using lactic acid bacteria-fermented soybean 
extract (Biofermentics ${ }^{\mathrm{TM}}$ )," Evidence-Based Complementary and Alternative Medicine, vol. 6, no. 3, pp. 357-363, 2009.

[22] M. A. Ghafar, E. Golliday, J. Bingham, M. M. Mansukhani, A. G. Anastasiadis, and A. E. Katz, "Regression of prostate cancer following administration of genistein combined polysaccharide $\left(\mathrm{GCP}^{\mathrm{TM}}\right)$, a nutritional supplement: a case report," Journal of Alternative and Complementary Medicine, vol. 8, no. 4, pp. 493-497, 2002.

[23] S. L. Badole and S. L. Bodhankar, "Investigation of antihyperglycemic activity of Glycine max (L.) Merr. on serum glucose level in diabetic mice," Journal of Complementary and Integrative Medicine, vol. 6, no. 1, p. 4, 2009.

[24] M. W. Grzanna, S. L. Ownby, L. F. Heinecke, A. Y. Au, and C. G. Frondoza, "Inhibition of cytokine expression and prostaglandin E2 production in monocyte/macrophage-like cells by avocado/soybean unsaponifiables and chondroitin sulfate," Journal of Complementary and Integrative Medicine, vol. 7, no. 1, article no. 10, 2010.

[25] J. R. Zhou, P. Mukherjee, E. T. Gugger, T. Tanaka, G. L. Blackburn, and S. K. Clinton, "Inhibition of murine bladder tumorigenesis by soy isofiavones via alterations in the cell cycle, apoptosis, and angiogenesis," Cancer Research, vol. 58, no. 22, pp. 5231-5238, 1998.

[26] R. Takahashi, R. Ohmori, C. Kiyose, Y. Momiyama, F. Ohsuzu, and K. Kondo, "Antioxidant activities of black and yellow soybeans against low density lipoprotein oxidation," Journal of Agricultural and Food Chemistry, vol. 53, no. 11, pp. 45784582, 2005.

[27] R. T. Wu, "Use of black soybean for treating ophthalmic diseases," Patent Pub. No. WO/2009/108577 International Application No.: PCT/US2009/034712.IPC: A61K36/48 (2006.01), A61K9/08 (2006.01), A61P27/ (2006. 02).

[28] S. M. Liu, H. F. Liao, and T. C. Lin, "Black soybean polysaccharide," United States Patent 68380 Application Number: 10/170159 Publication Date:01/04/2005 Filing Date:06/12/2002.

[29] S. Oshima, "It's a drink and a snack: black soybeans," The Japan Times, July 2000.

[30] J. S. Byun and S. S. Lee, "Effect of soybeans and sword beans on bone metabolism in a rat model of osteoporosis," Annals of Nutrition and Metabolism, vol. 56, no. 2, pp. 106-112, 2010.

[31] E. H. Jang, J. H. Ko, C. W. Ahn et al., "In vivo and in vitro application of black soybean peptides in the amelioration of endoplasmic reticulum stress and improvement of insulin resistance," Life Sciences, vol. 86, no. 7-8, pp. 267-274, 2010.

[32] I. T. Nizamutdinova, Y. M. Kim, J. I. Chung et al., "Anthocyanins from black soybean seed coats stimulate wound healing in fibroblasts and keratinocytes and prevent inflammation in endothelial cells," Food and Chemical Toxicology, vol. 47, no. 11, pp. 2806-2812, 2009.

[33] I. T. Nizamutdinova, Y. M. Kim, J. I. Chung et al., "Anthocyanins from black soybean seed coats preferentially inhibit TNF- $\alpha$-mediated induction of VCAM-1 over ICAM1 through the regulation of GATAs and IRF-1," Journal of Agricultural and Food Chemistry, vol. 57, no. 16, pp. 73247330, 2009.

[34] K. Tsoyi, B. P. Hyeong, Y. M. Kim et al., "Anthocyanins from black soybean seed coats inhibit UVB-induced inflammatory cylooxygenase- 2 gene expression and PGE production through regulation of the nuclear factor- $\kappa \mathrm{B}$ and phosphatidylinositol 3-kinase/Akt pathway," Journal of Agricultural and Food Chemistry, vol. 56, no. 19, pp. 8969-8974, 2008.
[35] S. H. Kwon, I. S. Ahn, S. O. Kim et al., "Anti-obesity and hypolipidemic effects of black soybean anthocyanins," Journal of Medicinal Food, vol. 10, no. 3, pp. 552-556, 2007.

[36] T. Koide, Y. Hashimoto, H. Kamei, T. Kojima, M. Hasegawa, and K. Terabe, "Antitumor effect of anthocyanin fractions extracted from red soybeans and red beans in vitro and in vivo," Cancer Biotherapy \& Radiopharmaceuticals, vol. 12, no. 4, pp. 277-280, 1997.

[37] J. H. Wong and T. B. Ng, "Isolation and characterization of a glucose/mannose-specific lectin with stimulatory effect on nitric oxide production by macrophages from the emperor banana," International Journal of Biochemistry and Cell Biology, vol. 38, no. 2, pp. 234-243, 2006.

[38] H. X. Wang and T. B. Ng, "Concurrent isolation of a Kunitztype trypsin inhibitor with antifungal activity and a novel lectin from Pseudostellaria heterophylla roots," Biochemical and Biophysical Research Communications, vol. 342, no. 1, pp. 349353, 2006.

[39] A. H. K. Cheung, J. H. Wong, and T. B. Ng, "Trypsinchymotrypsin inhibitors from Vigna mungo seeds," Protein and Peptide Letters, vol. 16, no. 3, pp. 277-284, 2009.

[40] X. Zhang, H. Wang, and B. N. Tzi, "Isolation and characterization of a novel trypsin inhibitor from fresh lily bulbs," Planta Medica, vol. 74, no. 5, pp. 546-550, 2008.

[41] X. Y. Ye and T. B. Ng, "Mungin, a novel cyclophilin-like antifungal protein from the mung bean," Biochemical and Biophysical Research Communications, vol. 273, no. 3, pp. 1111-1115, 2000.

[42] M. J. Camarasa, S. Velázquez, A. San-Félix, M. J. Pérez-Pérez, and F. Gago, "Dimerization inhibitors of HIV-1 reverse transcriptase, protease and integrase: a single mode of inhibition for the three HIV enzymes?" Antiviral Research, vol. 71, no. 2-3, pp. 260-267, 2006.

[43] V. R. de Soultrait, C. Desjobert, and L. Tarrago-Litvak, "Peptides as new inhibitors of HIV-1 reverse transcriptase and integrase," Current Medicinal Chemistry, vol. 10, no. 18, pp. 1765-1778, 2003.

[44] M. Böttcher and F. Grosse, "HIV-1 protease inhibits its homologous reverse transcriptase by protein-protein interaction," Nucleic Acids Research, vol. 25, no. 9, pp. 1709-1714, 1997.

[45] Y. Sato, S. Okuyama, and K. Hori, "Primary structure and carbohydrate binding specificity of a potent anti-HIV lectin isolated from the filamentous cyanobacterium Oscillatoria agardhii," Journal of Biological Chemistry, vol. 282, no. 15, pp. 11021-11029, 2007.

[46] L. Gattegno, A. Ramdani, T. Jouault, L. Saffar, and J. C. Gluckman, "Lectin-carbohydrate interactions and infectivity of human immunodeficiency virus type 1 (HIV-1)," AIDS Research and Human Retroviruses, vol. 8, no. 1, pp. 27-37, 1992.

[47] L. Hammar, I. Hirsch, A. A. Machado et al., "Lectin-mediated effects on HIV type 1 infection in vitro," AIDS Research and Human Retroviruses, vol. 11, no. 1, pp. 87-95, 1995.

[48] E. H. W. Leung, J. H. Wong, and T. B. Ng, "Concurrent purification of two defense proteins from French bean seeds: a defensin-like antifungal peptide and a hemagglutinin," Journal of Peptide Science, vol. 14, no. 3, pp. 349-353, 2008.

[49] J. H. Wong and T. B. Ng, "Purification of a trypsin-stable lectin with antiproliferative and HIV-1 reverse transcriptase inhibitory activity," Biochemical and Biophysical Research Communications, vol. 301, no. 2, pp. 545-550, 2003.

[50] J. Ho Wong and T. B. Ng, "A homotetrameric agglutinin with antiproliferative and mitogenic activities from haricot beans," 
Journal of Chromatography B, vol. 828, no. 1-2, pp. 130-135, 2005.

[51] S. H. Choi, Y. L. Su, and B. P. Won, "Mistletoe lectin induces apoptosis and telomerase inhibition in human A253 cancer cells through dephosphorylation of Akt," Archives of Pharmacal Research, vol. 27, no. 1, pp. 68-76, 2004.

[52] C. Ganguly and S. Das, "Plant lectins as inhibitors of tumour growth and modulators of host immune response," Chemotherapy, vol. 40, no. 4, pp. 272-278, 1994.

[53] T. Hajtó, K. Hostanska, T. Berki, L. Pálinkás, F. Boldizsár, and P. Németh, "Oncopharmacological perspectives of a plant lectin (Viscum album agglutinin-I): overview of recent results from in vitro experiments and in vivo animal models, and their possible relevance for clinical applications," Evidence-Based Complementary and Alternative Medicine, vol. 2, no. 1, pp. 5967, 2005.

[54] T. Hajtó, K. Fodor, P. Perjési, and P. Németh, "Difficulties and perspectives of immunomodulatory therapy with mistletoe lectins and standardized mistletoe extracts in evidence-based medicine," Evidence-Based Complementary and Alternative Medicine, vol. 2011, Article ID 298972, 6 pages, 2011.

[55] W. B. Park, S. Y. Lyu, J. H. Kim et al., "Inhibition of tumor growth and metastasis by Korean mistletoe lectin is associated with apoptosis and antiangiogenesis," Cancer Biotherapy \& Radiopharmaceuticals, vol. 16, no. 5, pp. 439-447, 2001.

[56] S. Moriwaki, H. Ohba, O. Nakamura et al., "Biological activities of the lectin, abrin-a, against human lymphocytes and cultured leukemic cell lines," Journal of Hematotherapy and Stem Cell Research, vol. 9, no. 1, pp. 47-53, 2000.

[57] M. O. Kim, D. O. Moon, J. M. Jung, W. S. Lee, Y. H. Choi, and G. Y. Kim, "Agaricus blazei extract induces apoptosis through ROS-dependent JNK activation involving the mitochondrial pathway and suppression of constitutive NF $\kappa$ B in THP-1 cells," Evidence-Based Complementary and Alternative Medicine. In press.

[58] S. K. Lam and T. B. Ng, "First report of a haemagglutinininduced apoptotic pathway in breast cancer cells," Bioscience Reports, vol. 30, no. 5, pp. 307-317, 2010.

[59] V. Ramnath, P. S. Rekha, G. Kuttan, and R. Kuttan, "Regulation of caspase-3 and Bcl-2 expression in Dalton's lymphoma ascites cells by Abrin," Evidence-Based Complementary and Alternative Medicine, vol. 6, no. 2, pp. 233-238, 2009.

[60] O. Gozia, J. Ciopraga, T. Bentia et al., "Antifungal properties of lectin and new chitinases from potato tubers," FEBS Letters, vol. 370, pp. 245-249, 1993.

[61] P. Verheyden, J. Pletinckx, D. Maes et al., "H NMR study of the interaction of $N, N^{\prime}, N^{\prime \prime}$-triacetyl chitotriose with AcAMP2, a sugar binding antimicrobial protein isolated from Amaranthus caudatus," FEBS Letters, vol. 370, no. 3, pp. 245249, 1995.

[62] X. Y. Ye, H. X. Wang, and T. B. Ng, "Sativin: a novel antifungal miraculin-like protein isolated from legumes of the sugar snap Pisum sativum var. macrocarpon," Life Sciences, vol. 67, no. 7, pp. 775-781, 2000.

[63] J. H. Wong, C. C. T. Wong, and T. B. Ng, "Purification and characterization of a galactose-specific lectin with mitogenic activity from pinto beans," Biochimica et Biophysica Acta, vol. 1760, no. 5, pp. 808-813, 2006.

[64] V. S. M. Ho and T. B. Ng, "A Bowman-Birk trypsin inhibitor with antiproliferative activity from Hokkaido large black soybeans," Journal of Peptide Science, vol. 14, no. 3, pp. 278282, 2008.

[65] M. Yamai, K. Tsumura, M. Kimura, S. Fukuda, T. Murakami, and Y. Kimura, "Antiviral activity of a hot water extract of black soybean against a human respiratory illness virus," Bioscience, Biotechnology and Biochemistry, vol. 67, no. 5, pp. 1071-1079, 2003.

[66] J. M. Kim, J. S. Kim, H. Yoo, M. G. Choung, and M. K. Sung, "Effects of black soybean [Glycine max (L.) merr.] seed coats and its anthocyanidins on colonic inflammation and cell proliferation in vitro and in vivo," Journal of Agricultural and Food Chemistry, vol. 56, no. 18, pp. 8427-8433, 2008.

[67] M. H. Ravindranath, S. Muthugounder, N. Presser, and S. Viswanathan, "Anticancer therapeutic potential of soy isoflavone, genistein," Advances in Experimental Medicine and Biology, vol. 546, pp. 121-165, 2004.

[68] Y. Li, J. Dong, J. Li, D. Wang, J. Piao, and X. Yang, "Stability of protein to digestion in vitro," Wei Sheng Yan Jiu, vol. 33, no. 4, pp. 433-437, 2004.

[69] K. Zhu-Salzman, P. K. Hammen, R. A. Salzman et al., "Calcium modulates protease resistance and carbohydrate binding of a plant defense legume lectin, Griffonia simplicifolia lectin II (GSII)," Comparative Biochemistry and Physiology B, vol. 132, no. 2, pp. 327-334, 2002.

[70] A. H. K. Cheung, J. H. Wong, and T. B. Ng, "Musa acuminata (Del Monte banana) lectin is a fructose-binding lectin with cytokine-inducing activity," Phytomedicine, vol. 16, no. 6-7, pp. 594-600, 2009. 


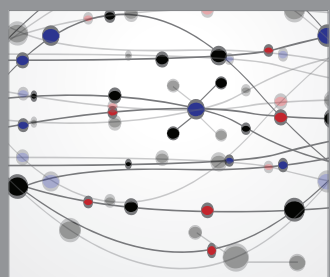

The Scientific World Journal
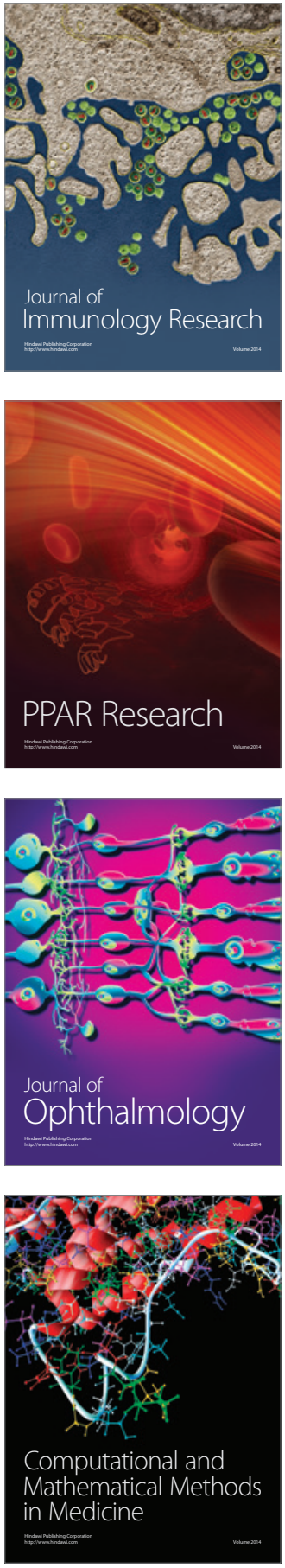

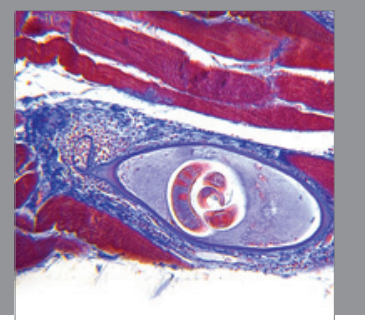

Gastroenterology

Research and Practice
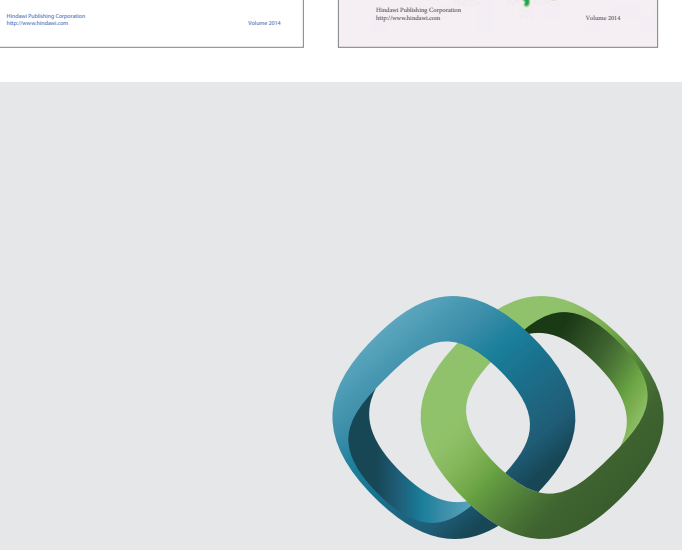

\section{Hindawi}

Submit your manuscripts at

http://www.hindawi.com
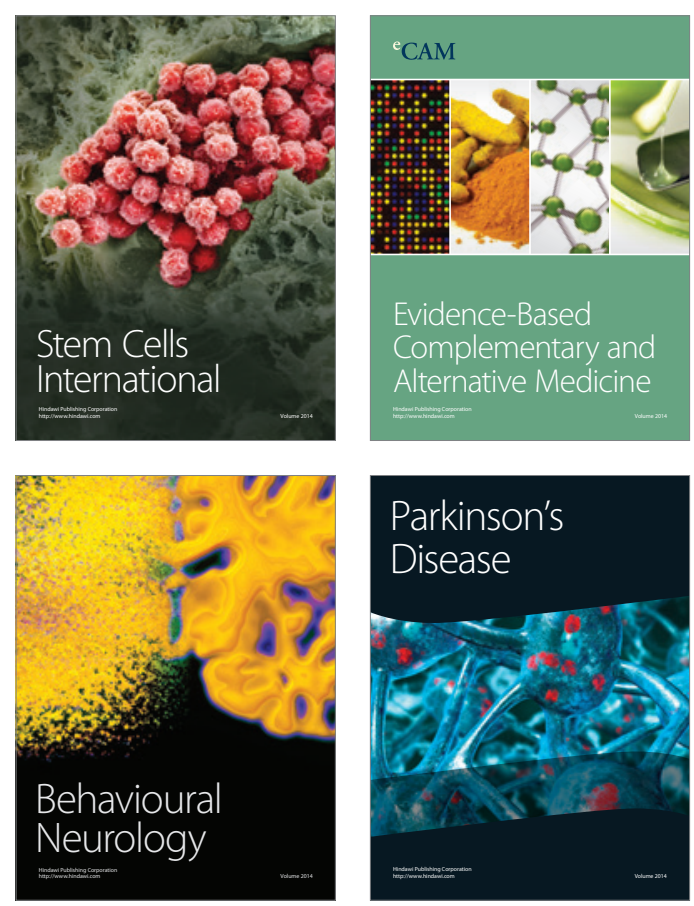

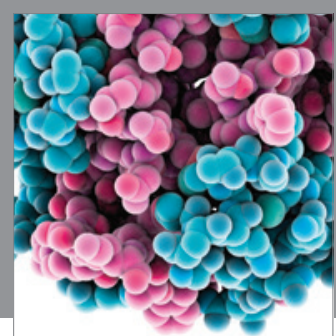

Journal of
Diabetes Research

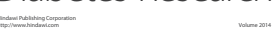

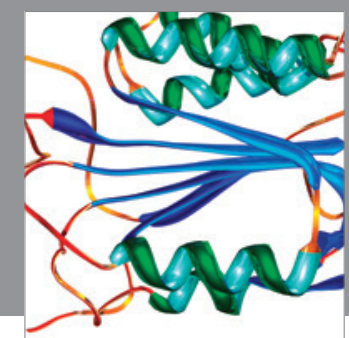

Disease Markers
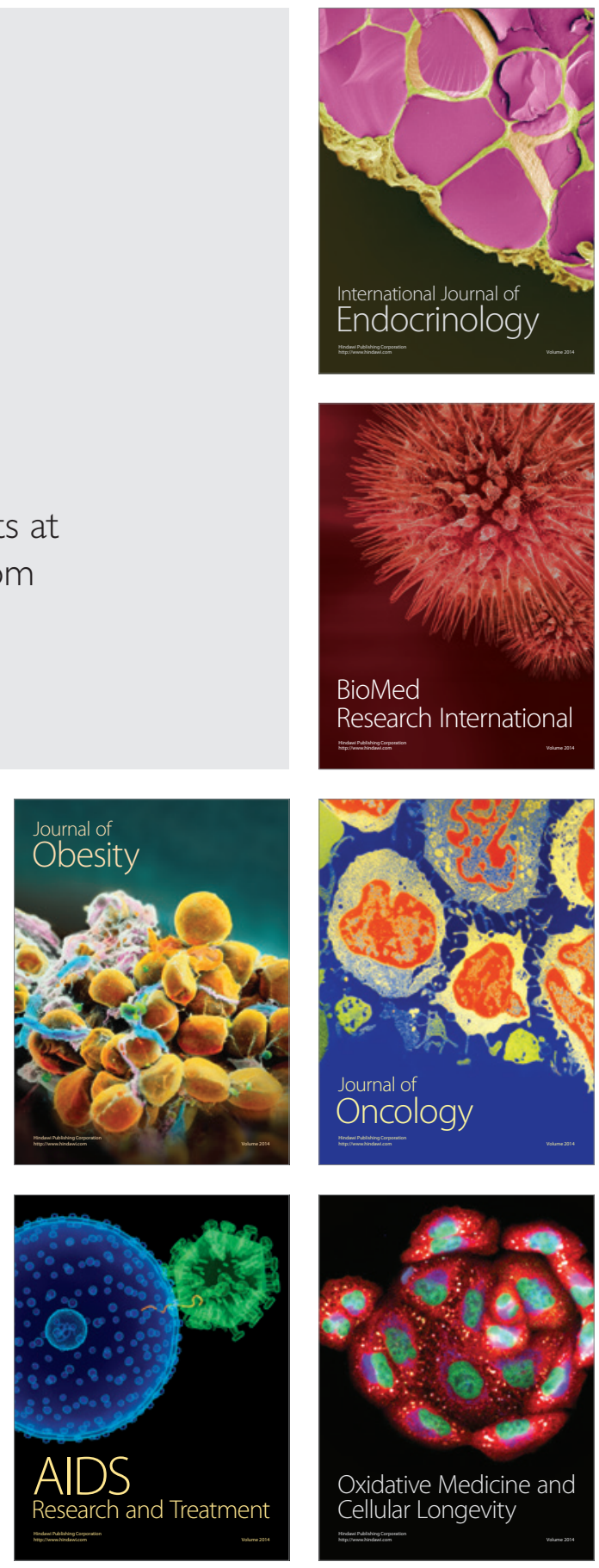